\title{
UPAYA PENCAPAIAN KEMAMPUAN PENALARAN MATEMATIKA SISWA MELALUI PEMBELAJARAN DENGAN PENDEKATAN METAKOGNITIF
}

\author{
Fina Milawati ${ }^{1}$, Timbo Faritcan Parlaungan Siallagan ${ }^{2}$ \\ ${ }^{1}$ STKIP Subang, ${ }^{2}$ STMIK Subang \\ 1finamilawati@yahoo.com , ${ }^{2}$ timbosiallagan@yahoo.co.id
}

\begin{abstract}
For the development of education towards more advanced learning mathematics sought metacognitive learning. Learning that can build students' perspectives on mathematical problems, by thinking of an appropriate strategy. Then, from the knowledge obtained by the student is able to draw conclusions or reasoning, in this case the achievement of students' mathematical reasoning abilities. This study aims to determine the achievement of the reasoning ability of students who are given learning with a metacognitive approach and students who are given conventional learning. This study uses an experimental method conducted on eighth grade students of SMP Negeri 3 Kalijati. The sample selection is done randomly by selecting two classes from three classes. Of the two classes selected, class VIIIC as an experimental class whose learning uses a metacognitive approach and class VIIIB as a control class whose learning uses conventional learning models. To determine the ability of the two classes are given a preliminary test and a final test with the same questions. The results of the study concluded that students' reasoning abilities on the subject of the circle using learning metacognitive approaches were higher than using conventional learning.
\end{abstract}

Keyword : Reasonability Math, Metacognitive Approaches

\section{ABSTRAK}

Untuk pengembangan pendidikan kearah lebih maju dalam pembelajaran matematika diupayakan suatu pembelajaran metakognitif. Pembelajaran yang dapat membangun cara pandang siswa terhadap masalah matematika, dengan memikirkan suatu strategi yang tepat. Kemudian, dari pengetahuan yang diperoleh siswa tersebut mampu mengambil kesimpulan atau penalaran, dalam hal ini pencapaian kemampuan penalaran matematika siswa. Penelitian ini bertujuan untuk mengetahui pencapaian kemampuan penalaran siswa yang diberi pembelajaran dengan pendekatan metakognitif dan siswa yang diberi pembelajaran konvensional. Penelitian ini menggunakan metode eksperimen yang dilakukan pada siswa kelas VIII SMP Negeri 3 Kalijati. Pemilihan sampel dilakukan secara acak dengan memilih dua kelas dari tiga kelas. Dari dua kelas yang terpilih, kelas VIIIC sebagai kelas eksperimen yang pembelajarannya menggunakan pendekatan metakognitif dan kelas VIIIB sebagai kelas kontrol yang pembelajarannya menggunakan model pembelajaran konvensional. Untuk mengetahui kemampuan dari kedua kelas tersebut diberi tes awal dan tes akhir dengan soal yang sama. Hasil penelitian menyimpulkan bahwa kemampuan 
penalaran siswa pada pokok bahasan lingkaran menggunakan pembelajaran pendekatan metakognitif lebih tinggi daripada menggunakan pembelajaran konvesional.

Kata Kunci : Kemampuan Penalaran Matematika, Pendekatan Metakognitif

\section{A. Pendahuluan}

Pada era sekarang ini aspek kehidupan yang paling penting adalah pendidikan. Dengan pendidikan setiap manusia mampu untuk memecahkan masalah, mengambil keputusan mampu mengembangkan potensi diri. Dunia pendidikan dituntut dapat menghasilkan sumberdaya manusia (SDM) berkualitas, yang mampu mengatasi segala tantangan. Oleh karena itu, dunia pendidikan perlu dikembangkan kearah lebih maju lagi, sehingga menghasilkan SDM yang berkualitas. Perlunya pembaharuan dalam bidang pendidikan sebagai upaya penyeimbang tingginya perkembangan teknologi ini berbagai kesulitan harus diatasi sesuai dengan tujuan yang diinginkan.

$$
\text { Pelajaran matematika }
$$

merupakan salah satu pengetahuan yang sangat penting terutama dalam era teknologi pada saat ini. Karena pentingnya matematika maka perlu dipahami oleh seluruh masyarakat terutama siswa yang masih bersekolah. Untuk menguasai dan menciptakan teknologi di masa depan diperlukan penguasaan matematika sejak dini. Sehingga pelajaran matematika menjadi pelajaran wajib bagi siswa, baik pada jenjang pendidikan dasar dan pendidikan menengah. Matematika yang dipilih berdasarkan atau berorientasi kepada kepentingan dimasa depan untuk membekali siswa dalam kemampuan berpikir.

Kurikulum 2004 Berbasis Kompetensi (KBK) yang diperbaharui dengan Kurikulum Tingkat Satuan Pendidikan (KTSP) yang semestinya dilaksanakan pada setiap sekolah untuk memperbaiki sistem pendidikan nasional. Untuk mencapai masyarakat yang mampu menyesuaikan diri dengan perkembangan jaman saat ini dan saat mendatang yang semakin diperbaharui. Diharapkan para lulusan akan mampu memecahkan masalah kehidupan yang dihadapi, 
kemampuan memperoleh, mengelola dan memanfaatkan informasi untuk bertahan hidup.

Tujuan yang utama adalah apa yang diajarkan berguna dikemudian hari. Yakni membantu kita untuk dapat belajar terus dengan cara yang lebih mudah. Apa yang kita pelajari memungkinkan untuk memahami dan mengerti terhadap materi yang diajukan dalam kegiatan belajar mengajar, serta memperluas dan memperdalam

pengetahuan seseorang.

Melalui kegiatan belajar mengajar, diharapkan siswa tidak hanya menerima transfer ilmu pengetahuan dari guru, melainkan ikut terlibat didalamnya sehingga siswa dapat lebih memahami materi yang disampaikan guru. Namun pada kenyataannya pelaksanaan kegiatan belajar mengajar masih tetap menggunakan cara lama yaitu guru mengajar dan siswa mendengarkan apa yang diajarkan oleh guru.

Presseisen (Widianti, 2003: 3) menyatakan bahwa proses berpikir dihubungkan dengan berbagai perilaku dan mengharuskan adanya keterlibatan aktif dari pemikir. Hasil yang tercatat dari pemikir adalah terbangunnya pengetahuan, nalar dan proses pemecahan masalah. Strategi-strategi mereka peroleh secara sadar dalam menganalisa informasi yang diperolehnya ketika mereka menyelesaikan masalah.

Penalaran berkaitan erat dengan kegiatan pikiran atau akal manusia. Dengan bernalar manusia dihadapkan kepada suatu aturan atau dasar yang harus diperhatikan untuk dapat berpikir dengan tepat, teliti dan teratur agar tercapai suatu kebenaran. Kemampuan bernalar sudah seharusnya dimiliki oleh siswa yang belajar matematika. Melalui penalaran diharapkan siswa memperoleh pemahaman tentang materi yang disajikan disamping mampu berpikir logis, kritis, sistematis serta kreatif dan inovatif dalam mencari solusi pemecahan sebuah masalah.

Dalam banyak kejadian pendidikan kita gagal dalam mewujudkan individu yang mampu mengambil keputusan dan kemampuan dalam penalaran, Kemampuan bernalar saat ini dirasakan masih kurang. Menurut 
Citrawati (Tarwin, 2006: 2) menyatakan bahwa: 'Rendahnya prestasi belajar matematika diakibatkan oleh rendahnya daya serap siswa, yaitu hanya sebesar $30 \%$ sebagai akibat dari pembelajaran yang kurang bermakna. Selain itu pembelajaran yang berlangsung bersifat satu arah dimana proses belajar tidak merefleksikan proses sosial yang didalamnya terdapat interaksi, baik berupa dialog maupun diskusi antara siswa dengan siswa maupun antara siswa dengan guru. Sehingga daya nalar siswa tidak berkembang'. adanya kebutuhan terhadap materi ini. Prestasi belajar siswa pun ditentukan oleh kemampuan metakognitifnya dalam memahami sebaran materi pelajaran yang telah ditentukan kurikulum. Strategi metakognitif digunakan siswa dapat menentukan bagaimana cara belajar, bagaimana cara berpikir dan menggunakan strategi-strategi pada saat belajar matematika.

Kesadaran siswa dalam berpikir yang disebut dengan metakognitif, seperti Sharples \& Mathew (Syafaat, 2005: 21) mengemukaan bahwa pendekatan metakognitif dibutuhkan siswa untuk menguasai suatu jangkauan keterampilan intelektual khusus, kemudian mengumpulkan dan mengumpulkan kembali keterampilan-keterampilan ini kedalam strategi belajar yang tepat untuk satu masalah khusus atau isuisu dalam konsteks yang berbeda. Dari pandangan ini kemampuan penalaran akan tercapai dengan baik. Karena proses belajar dan berpikir melalui pendekatan.

\section{B. Metode Penelitian}

Metode yang digunakan dalam penelitian ini adalah metode eksperimen. Ruseffendi (2005: 35) menyatakan "penelitian eksperimen atau percobaan adalah penelitian yang benar-benar untuk melihat hubungan sebab akibat. Perlakuan yang kita lakukan terhadap variabel bebas kita lihat hasilnya pada variabel terikat". Metode ini dipilih untuk menyelidiki ada atau tidaknya pengaruh pemberian perlakuan tersebut.

Populasi dalam penelitian ini adalah seluruh siswa kelas VIII SMPN 3 Kalijati yang berjumlah tiga 
kelas. Untuk pelaksanaan penelitian diambil dua kelas sebagai sampel secara acak untuk dijadikan subyek penelitian dari populasi tersebut.

Sampel yang diambil sebanyak dua kelas dari tiga kelas anggota populasi. Satu kelas dijadikan kelas eksperimen dan satu kelas dijadikan kelas kontrol. Selanjutnya terpilih kelas VIII C sebagai kelas eksperimen dan kelas VIII B sebagai kelas kontrol masing-masing 40 orang siswa.

\section{Hasil Penelitian dan}

\section{Pembahasan}

Data yang diperoleh dari hasil penelitian adalah data kuantitatif dari hasil tes awal dan tes akhir, sedangkan data kualitatif diperoleh dari hasil angket, jurnal dan lembar observasi.

\section{Analisis Data Hasil Tes Awal}

Pada pengolahan hasil tes awal, digunakan data yang terdapat pada lampiran C.1, kemudian akan dianalisis sifat kenormalannya, homogenitas, serta ada tidaknya perbedaan kemampuan awal dari masing-masing kelas eksperimen dan kelas kontrol. a. Uji Normalitas

Uji ini dilakukan untuk mengetahui kedua kelas berasal dari populasi yang berdistribusi normal atau tidak berdistribusi normal. Untuk menguji distribusi dari masing-masing kelas data digunakan uji kolmogorovsmirnov.

b. Uji Normalitas Tes Awal Kelas Eksperimen

hipotesis yang akan diuji adalah sebagai berikut:

$H_{\circ}$ : Data hasil tes awal kelas eksperimen berdistribusi normal $\mathrm{H}_{1}$ : Data hasil tes awal kelas eksperimen tidak berdistribusi normal

Dengan mengambil taraf signifikansi 0,05 dan dari hasil pengujian diperoleh $\mathrm{P}$-value $>0,15$ disimpulkan bahwa hipotesis nol $(\mathrm{Ho})$ diterima. Artinya data hasil tes awal kelas eksperimen berdistribusi normal.

c. Uji Normalitas Tes Awal Kelas Kontrol

Hipotesis yang akan diuji adalah sebagai berikut:

$H_{\circ}$ : Data hasil tes awal kelas kontrol berdistribusi normal 
$\mathrm{H}_{1}$ : Data hasil tes awal kelas kontrol tidak berdistribusi normal

Dengan mengambil taraf signifikansi 0,05 dan dari hasil pengujian diperoleh $\mathrm{P}$-value $>0,15$ disimpulkan bahwa hipotesis nol $(\mathrm{Ho})$ diterima. Artinya data hasil tes awal kelas kontrol berdistribusi normal.

d. Uji Homogenitas

Uji ini dilakukan untuk mengetahui apakah masing-masing data yang diperoleh dari kedua kelas memiliki varians populasi yang sama atau berbeda.

Pasangan hipotesis yang akan diuji adalah sebagai berikut:

$H_{0}: \sigma_{1}^{2}=\sigma_{2}{ }^{2}$; kedua varian homogen

$H_{1}: \sigma_{1}^{2} \neq \sigma_{2}^{2} ;$ kedua varian tidak homogen

Berikut ini tampilan perhitungan menggunakan software Minitab 13 for window untuk menguji homogenitas.

e. Test for Equal Variances

Level1 nilai awal e

Level2 nilai awal $\mathrm{k}$

ConfLvl 95.0000

Bonferroni confidence intervals for standard deviations

\begin{tabular}{|c|c|c|c|c|}
\hline $\begin{array}{c}\text { Low } \\
\text { er }\end{array}$ & Sigma & Upper & $\mathrm{N}$ & $\begin{array}{c}\text { Factor } \\
\text { Levels }\end{array}$ \\
\hline $\begin{array}{c}7.6324 \\
6\end{array}$ & $\begin{array}{c}9.5776 \\
2\end{array}$ & $\begin{array}{c}12.772 \\
6\end{array}$ & $\begin{array}{c}4 \\
0\end{array}$ & $\begin{array}{c}\text { Eklai Awal } \\
\text { Ekperim } \\
\text { en }\end{array}$ \\
\hline $\begin{array}{c}6.1123 \\
3\end{array}$ & $\begin{array}{c}7.6700 \\
8\end{array}$ & $\begin{array}{c}10.228 \\
7\end{array}$ & 4 & $\begin{array}{c}\text { Nilai Awal } \\
\text { Kontrol }\end{array}$ \\
\hline
\end{tabular}

F-Test (normal distribution)

Test Statistic: 1.559

P-Value : 0.170

f. Uji Homogenitas Tes Awal

Dengan taraf signifikansi 0,05 dan membandingkannya dengan Pvalue $=0,170$ disimpulkan bahwa hipotesis nol $(\mathrm{Ho})$ diterima artinya data tes awal kedua kelas homogen.

g. Uji Kesamaan Dua Rerata

Sampel penelitian berasal dari populasi yang berdistribusi normal dan memiliki varians homogen. Maka syarat untuk melakukan uji kesamaan dua rerata telah dipenuhi.

Pasangan hipotesis nol dan hipotesis tandingannya adalah sebagai berikut:

$\mathrm{H}_{0}: \mu_{1}=\mu_{2} \quad$ Tidak terdapat perbedaan antara rerata kemampuan awal kelas eksperimen dengan kelas kontrol.

$H_{1}: \mu_{1} \neq \mu_{2}$ Terdapat perbedaan antara rerata kemampuan 
awal kelas eksperimen dengan kelas kontrol.

Tampilan pengujian hipotesis menggunakan software Minitab 13 for windows adalah sebagai berikut:

h. Two-Sample T-Test and CI: Nilai Awal Eksperimen, Nilai Awal Kontrol Two-sample T for nilai awal eksperimen vs nilai awal kontrol

\begin{tabular}{|c|c|c|c|c|}
\hline & $\mathrm{N}$ & Mean & $\begin{array}{c}\text { Standar } \\
\text { Deviasi }\end{array}$ & $\begin{array}{c}\text { SE } \\
\text { Mean }\end{array}$ \\
\hline $\begin{array}{c}\text { Nilai } \\
\text { Awal }\end{array}$ & 40 & 38,25 & 9,58 & 1,5 \\
\hline $\begin{array}{c}\text { Nilai } \\
\text { Aawal }\end{array}$ & 40 & 37,88 & 7,67 & 1,2 \\
\hline
\end{tabular}

Difference $=$ mu nilai awal

eksperimen - mu nilai awal kontrol

Estimate for difference: 0.38

95\% $\mathrm{Cl}$ for difference: $(-3.49,4.24)$

T-Test of difference $=0$ (vs not $=$ )

$\mathrm{T}-$ Value $=0.19 \mathrm{P}$-Value $=0.847 \mathrm{DF}$

$=74$

Uji Kesamaan Dua Rerata Tes Awal

Dengan taraf signifikansi 0,05 kemudian dibandingkan $\mathrm{P}$-value $=$ 0,847 maka hipotesis nol ( $\mathrm{Ho})$ diterima artinya dengan taraf kepercayaan $\quad 0,95$ rata-rata kemampuan awal siswa pada kedua kelas tidak berbeda atau sama.

i. Analisis Data Hasil Tes Akhir

1) Uji Normalitas
Uji ini dilakukan untuk mengetahui kedua kelas berasal dari populasi yang berdistribusi normal atau tidak. Distribusi masing-masing data digunakan uji kolmogorovsmirnov.

2) Uji Normalitas Tes Akhir Kelas Eksperimen

Hipotesis yang akan diuji adalah sebagai berikut:

$H_{\circ}$ : Data hasil tes akhir kelas eksperimen berdistribusi normal

$\mathrm{H}_{1}$ : Data hasil tes akhir kelas eksperimen tidak berdistribusi normal

Dengan mengambil taraf signifikansi 0,05 dan dari hasil pengujian diperoleh $\mathrm{P}$-value $>0,15$ disimpulkan bahwa hipotesis nol $\left(\mathrm{H}_{0}\right)$ diterima. Artinya data hasil tes akhir kelas eksperimen berdistribusi normal.

3) Uji Normalitas Tes Akhir Kelas Kontrol

Hipotesis yang akan diuji adalah sebagai berikut:

$\mathrm{H}_{\mathrm{o}}$ : Data hasil tes akhir kelas kontrol berdistribusi normal

$\mathrm{H}_{1}$ : 
Dengan mengambil taraf signifikansi 0,05 dan dari hasil pengujian diperoleh $\mathrm{P}$-value $>0,15$, disimpulkan bahwa hipotesis nol $\left(\mathrm{H}_{\circ}\right)$ diterima. Artinya data hasil tes akhir kelas kontrol berdistribusi normal

4) Uji Homogenitas

Uji ini dilakukan untuk mengetahui apakah masing-masing data yang diperoleh dari kedua kelas memiliki varians populasi yang sama atau berbeda

Pasangan hipotesis yang akan diuji adalah sebagai berikut:

Ho $: \sigma_{1}^{2}=\sigma_{2}^{2}$; kedua varian homogen

$\mathrm{Hi}: \sigma_{1}^{2} \neq \sigma_{2}{ }^{2}$; kedua varian tidak homogen

Berikut ini tampilan perhitungan menggunakan software Minitab 13 for window untuk menguji homogenitas.

5) Test for Equal Variances

Level1 nilai akhir

Level2 nilai akhir

ConfLvl 95.0000

Bonferroni Confidence Intervals for Standard Deviations

\begin{tabular}{|c|c|c|c|c|}
\hline $\begin{array}{c}\text { Low } \\
\text { er }\end{array}$ & Sigma & Upper & $\mathrm{N}$ & $\begin{array}{c}\text { Factor } \\
\text { Levels }\end{array}$ \\
\hline $\begin{array}{c}6.1851 \\
6\end{array}$ & 7.7614 & 10.350 & 4 & nilai akhir \\
7 & 6 & 0 & eksperim \\
\hline
\end{tabular}

\begin{tabular}{|c|c|c|c|c|}
\hline & & & & en \\
\hline 6.0453 & 7.5860 & 10.116 & 4 & nilai akhir \\
6 & 4 & 7 & 0 & kontrol \\
\hline
\end{tabular}

F-Test (normal distribution)

Test Statistic: 1.047

P-Value : 0.887

6) Gambar Uji Homogenitas Tes

Akhir

Dengan taraf signifikansi 0,05 dan membandingkannya dengan Pvalue $=0,887$ disimpulkan bahwa hipotesis nol $(\mathrm{Ho})$ diterima artinya data tes akhir kedua kelas homogen. 7) Uji Kesamaan Dua Rerata

Sampel penelitian berasal dari populasi yang berdistribusi normal dan memiliki varians homogen. Maka syarat untuk melakukan uji kesamaan dua rerata telah dipenuhi.

Pasangan hipotesis nol dan hipotesis tandingannya adalah sebagai berikut:

Ho $: \mu_{1}=\mu_{2}$ Tidak terdapat perbedaan rerata kemampuan akhir kelas eksperimen dengan kelas kontrol.

$\mathrm{Hi}: \mu_{1}>\mu_{2}$ Rerata kemampuan akhir kelas eksperimen lebih tinggi dari kelas kontrol. 
Tampilan pengujian hipotesis menggunakan software Minitab 13 for windows adalah sebagai berikut:

8) Two-Sample T-Test and $\mathrm{Cl}$ : nilai akhir eksperimen, nilai akhir kontrol

Two-sample T for Nilai Akhir Eksperimen Vs Nilai Akhir Kontrol

\begin{tabular}{|c|c|c|c|c|}
\hline & $\mathrm{N}$ & Mean & $\begin{array}{c}\text { Standar } \\
\text { Deviasi }\end{array}$ & $\begin{array}{c}\text { SE } \\
\text { Mean }\end{array}$ \\
\hline $\begin{array}{c}\text { Nilai } \\
\text { Akhir }\end{array}$ & 40 & 77,63 & 7,76 & 1,2 \\
\hline $\begin{array}{c}\text { Nilai } \\
\text { Akhir }\end{array}$ & 40 & 62,88 & 7,59 & 1,2 \\
\hline
\end{tabular}

Difference $=$ mu nilai akhir eksperimen - mu nilai akhir kontrol Estimate for difference: 14.75 $95 \%$ lower bound for difference:

11.89

T-Test of difference $=0$ (vs >): T-

Value $=8.60 \mathrm{P}$-Value $=0.000 \mathrm{DF}=$ 77

Dengan taraf signifikansi 0,05 kemudian dibandingkan $\mathrm{P}$-value $=$ 0,000 maka hipotesis nol (Ho) ditolak artinya dengan taraf kepercayaan 0,95 rata-rata kemampuan akhir siswa pada kelas eksperimen lebih baik daripada kelas kontrol.

j. Analisis Data Peningkatan Penalaran (Gain) Matematika
1) Deskripsi Statistik Peningkatan Penalaran Matematika (Gain)

Data gain merupakan dari selisih nilai tes akhir dengan tes awal sehingga didapat peningkatan kemampuan penalaran matematika siswa. Dengan menggunakan program Minitab 13 for windows maka gambar deskripsi kelas eksperimen adalah :

Descriptive Statistics: Gain Kelas Eksperimen

\begin{tabular}{|l|l|l|c|c|c|c|}
\hline $\begin{array}{l}\text { Varie } \\
\text { able }\end{array}$ & $\mathrm{N}$ & $\begin{array}{c}\text { Mea } \\
\mathrm{n}\end{array}$ & $\begin{array}{c}\text { Me } \\
\text { dia } \\
\mathrm{n}\end{array}$ & $\begin{array}{c}\text { TrM } \\
\text { ean }\end{array}$ & $\begin{array}{c}\text { St } \\
\text { De } \\
\mathrm{v}\end{array}$ & $\begin{array}{c}\mathrm{SE} \\
\mathrm{Me} \\
\mathrm{an}\end{array}$ \\
\hline $\begin{array}{l}\text { Gain } \\
\text { Kel }\end{array}$ & 40 & $\begin{array}{l}39,3 \\
8\end{array}$ & $\begin{array}{c}40, \\
00\end{array}$ & $\begin{array}{l}39, \\
17\end{array}$ & $\begin{array}{c}12, \\
62\end{array}$ & $\begin{array}{l}2,0 \\
0\end{array}$ \\
\hline $\begin{array}{c}\text { Mini } \\
\text { mum }\end{array}$ & $\begin{array}{c}\text { Maxi } \\
\text { mum }\end{array}$ & \multicolumn{2}{|c|}{$\mathrm{Q} 1$} & $\mathrm{Q} 3$ \\
\hline $\begin{array}{l}\text { Varia } \\
\text { bel } \\
\text { Gain } \\
\text { Kel }\end{array}$ & $\begin{array}{c}15,0 \\
0\end{array}$ & $\begin{array}{c}65,0 \\
0\end{array}$ & \multicolumn{2}{|c|}{30,00} & 48,75 \\
\hline
\end{tabular}

Adapun dari deskripsi gain kelas eksperimen di dapat bahwa rata-rata gain kelas eksperimen adalah 39,38. Nilai gain minimum adalah 15,00 dan nilai gain maksimum adalah 65,00.

Kemudian adapun gambaran deskriptif statistik kelas kontrol dengan kemudian menggunakan 
Software Minitab 13 for windows

adalah sebagai berikut :

Dari deskripsi gain kelas eksperimen di dapat bahwa rata-rata gain kelas eksperimen adalah 25,00. Nilai gain minimum adalah 5,00 dan nilai gain maksimum adalah 45,00.

Setelah melihat deskripsi statistik data gain diatas, nilai rerata gain kelas eksperimen sebesar 39,375 dan nilai rerata gain kelas kontrol sebesar 25,000 maka dapat disimpulkan bahwa perbedaan pencapaian kemampuan penalaran matematika siswa sebesar 14,375.

2) Uji Kesamaan Dua Rerata Gain

Selanjutnya akan diuji tingkat signifikasi kemampuan penalaran matematika siswa (gain) dengan menggunakan pendekatan metakognitif.

Rumusan hipotesis adalah :

$\mathrm{H}_{\mathrm{o}}: \mu_{1}=\mu_{2}$; Tidak terdapat pencapaian

kemampuan

penalaran

matematika siswa.

$\mathrm{H}_{1}: \quad \mu_{1} \neq \mu_{2} \quad ; \quad$ Terdapat pencapaian kemampuan penalaran matematika

siswa.

Untuk menghitung kesamaan dua rerata tes gain digunakan program Softwere Minitab 13 for windows dengan tampilan sebagai berikut :

3) Two-Sample T-Test and Cl: Gain

Eksperimen, Gain Kontrol

Two-sample $T$ for gain eksperimen vs gain kontrol

\begin{tabular}{|l|c|c|c|c|}
\hline & $\mathrm{N}$ & Mean & StDev & $\begin{array}{c}\text { SE } \\
\text { Mean }\end{array}$ \\
\hline $\begin{array}{l}\text { Gain } \\
\text { Eksperimen }\end{array}$ & 40 & 39,40 & 12,60 & 2,0 \\
\hline Gain Kontrol & 40 & 25,00 & 8,70 & 1,4 \\
\hline
\end{tabular}

Difference $=$ mu gain eksperimen mu gain kontrol

Estimate for difference: 14.38

95\% lower bound for difference:

10.34

T-Test of difference $=0$ (vs $>$ ): T-

Value $=5.93 \mathrm{P}$-Value $=0.000 \mathrm{DF}=$ 69

4) Uji Kesamaan Dua Rerata Gain

Dengan taraf signifikansi 0,05 dibandingkan dengan $\mathrm{P}$-value 0,000 maka Ho ditolak. Artinya dengan taraf kepercayaan 0,95 rata-rata Gain siswa pada kelas eksperimen lebih tinggi dibandingkan kelas kontrol. 


\section{Kesimpulan}

Berdasarkan hasil analisis data dan pengujian hipotesis maka penulis dapat menarik kesimpulan bahwa:

1. Melalui pembelajaran dengan pendekatan metakognitif yang membangun kesadaran siswa dalam berpikir, terdapat adanya pencapaian kemampuan penalaran matematika siswa.

2. Kemampuan penalaran siswa yang menggunakan pembelajaran dengan pendekatan metakognitif lebih baik daripada kemampuan penalaran siswa yang menggunakan model pembelajaran konvensional.

3. Sikap siswa menunjukan respon positif terhadap penerapan pendekatan metakognitif untuk pencapaian kemampuan penalaran.

\section{DAFTAR PUSTAKA}

Barkah, S (2005) Pengaruh pendekatan Keterampilan Metakognitif Dalam Pembelajaran Matematika Siswa. Skripsi FPMIPA UPI. Bandung (tidak diterbitkan).

Hasanah, Rinanuruswatun (2008). Pembelajaran Matematika dengan pendekatan keterampilan Metakognitif untuk menigkatkan kemampuan penalaran siswa. STKIP Subang (tidak diterbitkan).
Kuraesin, E (2004). Pengembangan Kemampuan Penalaran dan Komnikasi Matematika Siswa SLTP Melalui Model Pembelajaran dengan Pendekatan Pemecahan Masalah. STKIP Subang (tidak diterbitkan)

Ruseffendi (2005). Dasar-dasar Penelitian Pendidikan dan Bidang Noneksakta lainnya. Bandung: Tarsito.

Syafaat, A (2005). Pembelajaran dengan Pendekatan Keterampilan Metakognitif untuk Mengembangkan Kompetensi Siswa. Skripsi FPMIPA UPI Bandung (tidak diterbitkan)

Sudjana, Nana (1992). Penilaian Hasil Proses Belajar Mengajar. Bandung : PT.Remaja Rosdakarya.

Suherman, dkk (2001). Strategi pembelajaran Matematika Kontemporer. JICA UPI Bandung (tidak diterbitkan).

Suherman,(2003).Evaluasi Pembelajaran Matematika untuk Guru dan Mahasiswa Calon Guru Matematika. Bandung : UPI

Widianti, D (2003). Penerapan pembelajaran Metakognitif Dalam Upaya Meningkatkan Komunikasi Matematika Siswa SMU

Yamin, Martinis (2003). Strategi Pembelajaran Berbasis Kompetensi. Penerbit: GP Press. 